Rev. Inst. Med. trop. S. Paulo

41 (3): 151-154, May-June, 1999.

\title{
DETECTION OF A Giardia lamblia COPROANTIGEN BY USING A COMMERCIALLY AVAILABLE IMMUNOENZYMATIC ASSAY, IN BELO HORIZONTE, BRAZIL
}

\author{
Míriam Oliveira e ROCHA, Rômulo Teixeira de MELLO, Tânia Mara Pinto Dabés GUIMARÃES, \\ Vicente de Paulo Coelho Peixoto de TOLEDO, Maria da Conceição Carneiro Gonçalves MOREIRA \& Carlos Alberto da COSTA
}

\begin{abstract}
SUMMARY
It is known that fecal examination to detect Giardia lamblia cysts or trophozoites produces a high percentage of false-negative results. A commercially available immunoenzymatic assay (ProSpecT Giardia Microplate Assay, Alexon, Inc., BIOBRÁS) to detect G. lamblia specific coproantigen was evaluated for the first time in Brazil. A total of 90 specimens were tested. Each specimen was first tested as unpreserved stool, and then it was preserved in $10 \%$ Formalin to be tested 2 months later. The assay was able to identify all the 30 positive patients (sensitivity $=100.0 \%$ ) by visual or spectrophotometric examination in the unpreserved specimens and was negative in 57 of the 60 patients without $G$. lamblia (specificity $=95.0 \%$ ). The assay identified 27 of the 30 positive patients (sensitivity $=90.0 \%$ ) and was negative in 59 of the 60 negatives (specificity $=98.3 \%$ ) in the preserved stools according to both readings. A marked difference was observed in the optical densities in both groups, preserved and unpreserved stools, when the G. lamblia-positive specimens were compared to the negative or positive for other intestinal parasites than G. lamblia. The assay seems a good alternative for giardiasis diagnosis, especially when the fecal examination was repeatedly negative and the patient presents giardiasislike symptoms.
\end{abstract}

KEYWORDS: Giardia lamblia; Coproantigen; Immunodiagnostic.

\section{INTRODUCTION}

Giardia lamblia is a flagellate protozoan found in the small intestine of humans and other animals ${ }^{26}$. It is broad worldly distributed, being detected in both developing and developed countries. It is the most commonly reported human intestinal parasite, with prevalence rates reaching 2 to $7 \%$, in the developed countries ${ }^{23,26}$. It is the leading infectious agent identified in the outbreaks of diarrhea in the United States. The prevalence rates may reach 20 to $60 \%$ in some areas in the developing countries ${ }^{9}$. It ranges between 13.8 to $63.3 \%$ for children in different Brazilian regions $3,7,12,27$. Other studies which include adults and children ${ }^{4,18,20}$ or only adults ${ }^{5}$, report prevalence rates of 18 to $22 \%$. A study carried out in the city of Rio de Janeiro involving under one year old children found $4.2 \%$ of G. lamblia-positive results. This protozoan and the Ascaris lumbricoides were the two first parasites found ${ }^{6}$. Since it is more frequent among eight months to ten year old children, it becomes a serious public health problem in this age group. The symptoms of giardiasis in humans are extremely variable. Some people may present the asymptomatic form, others an acute or chronic diarrhea that can last for several months with malabsortion syndrome and weight loss ${ }^{10,15}$. G. lamblia is usually pointed as one of the causes of children's retarded growth and development ${ }^{10}$.
The qualitative immunoenzymatic ProSpecT Giardia Microplate Assay was developed in the United States to detect a G. lamblia specific antigen (GSA 65) in aqueous stool eluates, which can be read visually or spectrophotometrically ${ }^{21}$. All the studies to verify the efficacy of the test were carried out in the United States ${ }^{1,21}$, except GOLDIN et al. (1990). Despite the excellent performance reported in these studies, the conditions of Brazilian patients, particularly concerning intestinal parasites and other gastrointestinal agents, are very different from those of the American people.

The ProSpecT Giardia Microplate Assay is also useful for epidemiologic investigation, especially in day-care settings and control of giardiasis outbreaks when it is necessary to preserve the stools. Some authors reported that the storage of stools as formalinized eluates did not affect the immunoenzymatic assay ${ }^{21,25}$. In contrast other studies ${ }^{14,28}$ related poor results in such conditions.

The current study evaluates the sensitivity and specificity of the ProSpecT Giardia Microplate Assay in fresh and formalinized stools of patients in Belo Horizonte, Brazil.

Clinical and Toxicological Analysis Departament, Pharmacy Faculty, Federal University of Minas Gerais, Brazil.

Correspondence to: Míriam Oliveira e Rocha, Departamento de Análises Clínicas e Toxicológicas, Faculdade de Farmácia da UFMG, Av. Olegário Maciel 2360, Caixa Postal 689,

30180-112 Belo Horizonte, MG, Brasil. E-mail: rob@gcsnet.com.br 


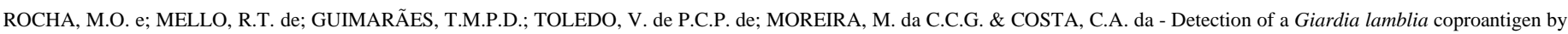
using a commercially available immunoenzymatic assay, in Belo Horizonte, Brazil. Rev. Inst. Med. trop. S. Paulo, 41(3): 151-154, 1999.

\section{MATERIAL AND METHODS}

\section{Fecal samples}

Ninety stool samples were collected of patients in Belo Horizonte, Brazil. For each patient three fecal samples collected in alternated days were examined microscopically for the presence of intestinal parasites, by the merthiolate-iodine-formalin concentration method (MIFC) ${ }^{2}$. Patients were considered $G$. lamblia negative when the three fecal samples presented no G. lamblia cysts or trophozoites. The fecal samples were divided into 2 groups:

Group 1: 30 G. lamblia-positive samples.

Group 2: 60 G. lamblia-negative samples. Thirty of these were positive for other intestinal parasites than G. lamblia.

Each specimen was first tested as unpreserved stool and then it was preserved in $10 \%$ Formalin to be tested 2 months later.

\section{Immunoenzymatic assay}

The immunoenzymatic assay was performed according to the instructions of the ProSpecT Giardia Microplate Assay (Alexon, Inc., BIOBRÁS), summarized as follows: $100 \mu \mathrm{L}$ of diluted stool specimens, positive and negative controls were added into the ProSpecT microplate wells, pre-coated with anti-GSA 65 monoclonal antibody. After 60 min incubation at room temperature, the wells were washed 5 times with the wash buffer to remove unbound materials. The enzyme conjugate (monoclonal anti-GSA antibody labelled with horseradish peroxidase enzyme) was added $-200 \mu \mathrm{L}$ and the microplate was incubated for 30 min at room temperature. The wells were washed other 5 times and, then, $200 \mu \mathrm{L}$ of the substrate for the enzyme was added. The reaction was stopped after $10 \mathrm{~min}$ incubation at room temperature with $50 \mu \mathrm{L}$ of the stop solution. Each stool sample was first tested as fresh one and so it was preserved in $10 \%$ Formalin to be tested again 2 months later. Reactions were read visually and spectrophotometrically at $450 \mathrm{~nm}$ and were interpreted according to the kit instructions:

Visual readings: the negative reaction is colorless and indicates that none or undetectable level of GSA 65 is present in the sample tested. The positive reaction develops yellow color of variable intensity.

Spectrophotometric readings: Positive tests have optical densities (O.D.) values $\geq 0.050$ after the blank of the Negative Control is subtracted, indicating that the sample tested contains GSA 65. The result is considered negative when it presents O.D. values $<0.050$.

\section{RESULTS}

The immunoenzymatic assay applied to the fresh stools (Table 1) by using visual or spectrophotometric readings, detected all the $30 \mathrm{G}$. lamblia-positive stools (sensitivity $=100.0 \%$ ) and was negative in 57 of 60 samples without $G$. lamblia (specificity $=95.0 \%$ ). Concerning the samples preserved in $10 \%$ Formalin for 2 months, the ProSpecT Giardia Microplate Assay, by using both readings (Table 1), detected 27 of 30 positive samples (sensitivity $=90.0 \%$ ) and was negative in 59 of $60 \mathrm{G}$. lamblia-negative specimens (specificity $=98.3 \%$ ).
Table 1

Sensitivity and specificity of ProSpecT Giardia Microplate Assay (visual and spectrophotometric readings ${ }^{*}{ }^{* *}$ to detect Giardia lamblia coproantigen using 90 fresh and preserved stool samples

\begin{tabular}{lcc|}
\hline & $\begin{array}{c}\text { Fresh stools } \\
\text { no. }(\%)\end{array}$ & $\begin{array}{c}\text { Preserved stools } \\
\text { no. }(\%)\end{array}$ \\
\hline Sensitivity & $30 / 30(100.0 \%)$ & $27 / 30(90.0 \%)$ \\
Specificity & $57 / 60(95.0 \%)$ & $59 / 60(98.3 \%)$ \\
\hline
\end{tabular}

$* 450 \mathrm{~nm}$

**The results obtained by using both readings were the same.

Figure 1 represents the O.D. readings obtained through the test of 90 stool samples. Negative stools and samples presenting other intestinal parasites than $G$. lamblia were clearly distinguished from the G. lamblia-positive ones, both in the unpreserved and preserved specimens. In the unpreserved stools the O.D. readings varied from 0.196 to 1.940 in the positive specimens, from 0.000 to 0.031 in the negative ones and from 0.000 to 0.419 in those presenting other intestinal parasites than G. lamblia, even though only three samples in this last group showed positive results, with O.D. readings of 0.117 in 2 samples and 0.419 in the other. The O.D. readings obtained with the stool samples preserved with $10 \%$ Formalin for 2 months varied from 0.000 to 2.000 in the positive group, from 0.000 to 0.249 in the negative one and from 0.000 to 0.038 in the stool samples presenting other intestinal parasites than G. lamblia. Only three specimens in the positive group showed negative O.D. readings $(0.000,0.000$ and 0.028$)$ and only one in the negative group presented positive O.D. reading (0.249). The fact that one stool became positive after storage in Formalin $10 \%$ for 2 months has to be more investigated. The other intestinal parasites found in the 30 stool samples without G. lamblia were: Ascaris lumbricoides (6), Trichuris trichiura (6), Ancylostomatidae (4), Strongyloides stercoralis (6), Schistosoma mansoni (1), Hymenolepis nana (1), Enterobius vermicularis (1), Entamoeba histolytica (4), Entamoeba coli (14), Iodamoeba butschlii (1), Endolimax nana (12). Several patients presented more than one intestinal parasite.

\section{DISCUSSION}

In spite of the importance of G. lamblia as one of the causes of diarrhea and malabsorption, its diagnosis is far from satisfactory ${ }^{25}$. A single microscopical examination of stool samples for the presence of parasite forms only detects 50 to $70 \%$ of the infected patients ${ }^{22,28}$ due to the intermittent shedding of parasite cysts and trophozoites in stool $^{8,19}$. Multiple stool examination increases this percentage to over $90 \%{ }^{16}$. Therefore, microscopical examination of stool can be time-consuming and expensive. Its sensitivity can be lower in chronic giardiasis $^{22}$. Examination of duodenal aspirate or small intestine biopsy are invasive, costly and unconfortable for the patient, particularly for children. Serum anti-Giardia antibody detection fails to distinguish current from past infection ${ }^{21,22}$. Antigen-capture enzyme-linked immunosorbent assay (ELISA) methods to detect G. lamblia antigen in stool proved to be useful in giardiasis diagnosis ${ }^{11,17,25,28}$.

The ProSpecT Giardia Microplate Assay was tested before in different laboratories ${ }^{1,21,24}$, but never in Brazil where the prevalence of intestinal parasites is high and several patients present more than one 


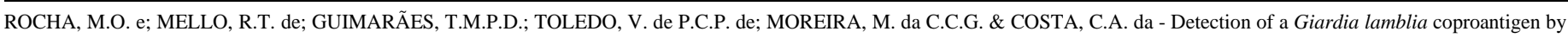
using a commercially available immunoenzymatic assay, in Belo Horizonte, Brazil. Rev. Inst. Med. trop. S. Paulo, 41(3): 151-154, 1999.

parasite. The sensitivity (100.0\%) and specificity (95.0\%) obtained in the current work with fresh stools, is in accordance with these studies.
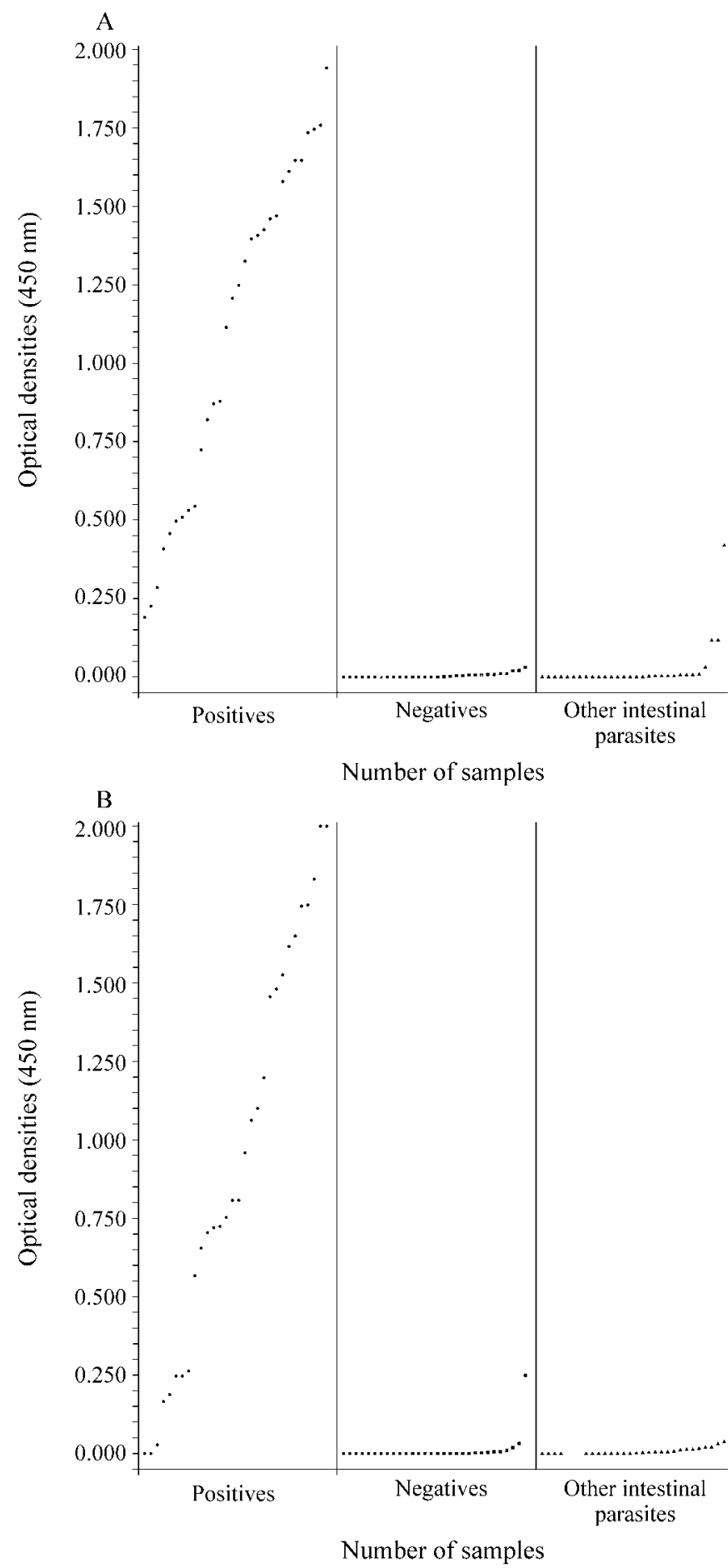

Fig. 1 - Detection of G. lamblia coproantigen by using the ProSpecT Giardia Microplate Assay (spectrophotometric readings) in G. lamblia positive $(\bullet)$ and negative $(\mathbf{\square})$ samples and presenting other intestinal parasites $(\boldsymbol{\Delta})$, according the microscopical examination $\mathrm{A}=90$ fresh stools; B $=90$ formolinazed stools, both of patients in Belo Horizonte, Brazil. Cut-off point $=0.050$
The test also showed high sensitivity (90.0\%) and specificity (98.3\%) when the stools were preserved in $10 \%$ Formalin for 2 months. The fact that $10 \%$ Formalin is often used to preserve the specimens to be sent to the laboratories allows us to conclude that the test is useful for individual diagnosis as well as for epidemiological purposes. In contrast, UNGAR et al. (1984) and KNISLEY et al. (1989) reported that the presence of $10 \%$ Formalin affects the immunoassay. However, the antigen to be captured in these assays was not the GSA 65. ROSOFF \& STIBBS (1986) showed it is stable in the presence of formaldehyde for long periods. The storage of stools for 6 months at $4{ }^{\circ} \mathrm{C}$ in water or in $10 \%$ Formalin did not affect GSA 65 detection ${ }^{21,25}$. ADDISS et al. (1991) reported the O.D. readings decreased when the test was performed with stools preserved in $10 \%$ Formalin for a long period. These authors suggest that the immunoassay should be performed few months after collection in such conditions. Our data show the stool storage in 10\% Formalin until 2 months did not affect the test $\left(\chi^{2}=0.62\right)$.

The immunoenzymatic assay was highly specific when performed with stool samples presenting other intestinal parasites than G. lamblia. It cannot be stated that the three positive results obtained in this group were due to cross-reactions because the test showed negative results in other samples with the same intestinal parasite. It is possible that these reactions most likely represent cryptic giardiasis rather than true crossreactions $^{21}$. Several immunoenzymatic assays to detect G. lamblia coproantigens use policlonal antibodies ${ }^{13,17,25}$. The ProSpecT Giardia Microplate Assay uses monoclonal antibody directed against a specific G. lamblia antigen (GSA 65$)^{21}$, what reduces the possibility of crossreactions. The literature does not report cross-reactions of anti-GSA 65 antibody with other intestinal parasites ${ }^{1,22}$.

The high agreement found between visual and spectrophotometric readings $(97.8 \%)$ eliminates the need of a microplate reader, allowing its use by those laboratories which do not have that equipment or for field studies.

The ProSpecT Giardia Microplate Assay showed to be a sensitive and specific diagnostic test for giardiasis. However, it should not substitute stool microscopical examination for ova and parasites as a routine diagnostic test because the latter can detect other intestinal parasites. The assay is an important diagnostic tool when the patient presents giardiasislike symptoms and the results of the fecal examination were repeatedly negative. The test is easy to perform, less time-consuming and allows the simultaneous processing of large numbers of samples.

\section{RESUMO}

\section{Avaliação do ProSpeT Giardia ensaio em microplaca na detecção de coproantígenos de Giardia lamblia, em fezes de pacientes de Belo Horizonte, Brasil}

O diagnóstico da giardíase através da pesquisa de trofozoítos ou cistos do parasita nas fezes apresenta uma elevada percentagem de resultados falso-negativos. No presente trabalho foi feita, pela primeira vez no Brasil, uma avaliação do ProSpecT Giardia Ensaio em Microplaca (Alexon, Inc., BIOBRÁS), utilizando amostras fecais de pacientes de Belo Horizonte, Brasil. Um total de 90 amostras fecais foram testadas, primeiramente como fezes frescas e, então, preservadas em formalina $10 \%$, para um novo teste 2 meses após. Com as amostras frescas, o ensaio imunoenzimático, através de leitura visual ou no espectrofotômetro, foi 


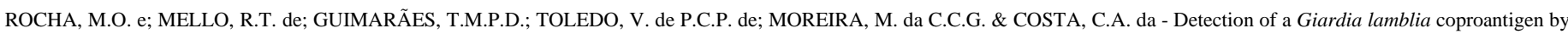
using a commercially available immunoenzymatic assay, in Belo Horizonte, Brazil. Rev. Inst. Med. trop. S. Paulo, 41(3): 151-154, 1999.

capaz de identificar todos os 30 pacientes positivos no exame parasitológico de fezes (EPF) e foi negativo em 57 dos 60 pacientes sem $G$. lamblia (sensibilidade $=100,0 \%$, especificidade $=95,0 \%$ ). Com as amostras preservadas em formalina $10 \%$ durante 2 meses, o teste identificou 27 das 30 amostras fecais positivas (sensibilidade $=90,0 \%$ ) e foi negativo em 59 das 60 amostras negativas no EPF (especificidade $=$ 98,3\%). Comparando-se as leituras das densidades óticas nas amostras fecais positivas para G. lamblia com as amostras com EPF negativo ou contendo outros parasitas intestinais que não a G. lamblia, foi observada uma nítida diferença, tanto nas fezes frescas como nas fezes conservadas em formalina 10\% durante 2 meses. O ProSpecT Giardia Ensaio em Microplaca mostrou-se uma boa alternativa para o diagnóstico da $G$. lamblia, especialmente para aqueles casos em que o EPF foi repetidamente negativo e o paciente apresenta sintomas compatíveis com a giardíase.

\section{ACKNOWLEDGMENTS}

We are grateful to Dr. Jair Zeringota Notini Pereira for having collected the stool samples at Posto de Saúde Nossa Senhora de Fátima, Belo Horizonte, Brazil, to Nádia Alves de Oliveira for revising the manuscript and to Geraldo Gomes Moreira for drawing the graphic. This work was supported in part by FAPEMIG.

\section{REFERENCES}

1. ADDIS, D.G.; MATHEWS, H.M.; STEWART, J.M. et al. - Evaluation of a commercially available enzyme-linked immunosorbent assay for Giardia lamblia antigen in stool. J. clin. Microbiol., 29: 1137-1142, 1991.

2. BLAGG, W.; SCHOLOEGEL, E.L.; MANSOUR, N.S. \& KALAF, G.I. - A new concentration technic for the demonstration of protozoa and helminth eggs in feces. Amer. J. trop. Med. Hyg., 4: 23-28, 1955.

3. COSTA, C.A. da; SANTOS, M.V.; ROCHA, M.O.; MELLO, R.T. \& BODAN, M.M.B. - Parasitoses intestinais em crianças da creche Lenor Franco (SESIMINAS-Contagem, MG): diagnóstico e terapêutica. Rev. Farm. Bioq. Univ. Fed. Minas Gerais, 9: $7-13,1988$

4. COSTA, M.S.G.; NUNES, M.P.O.; NUNES, J.F.L. \& SILVA, E.M.A. - Prevalência de enteroparasitoses em Natal, rotina coproscópica da parasitologia clínica-UFRN: estudo em um decênio. Rev. bras. Anál. Clín., 24: 103-107, 1992.

5. COSTA-CRUZ, J.M.; CARDOSO, M.L.G. \& MARQUES, D.E. - Intestinal parasites in school food handlers in the city of Uberlândia, Minas Gerais, Brazil. Rev. Inst. Med. trop. S. Paulo, 37: 191-196, 1995.

6. COSTA-MACEDO, L.M. da \& REY, L. - Frequency and precocity of human intestinal parasitism in a group of infants from Rio de Janeiro, Brazil. Rev. Inst. Med. trop. S. Paulo, 39: 305-306, 1997.

7. CURY, G.C.; SALLES, P.G.O.; REIS, M.C.W. et al. - Prevalência da esquistossomose mansoni e de parasitoses intestinais em escolares da área rural do Município de Jaboticatubas, MG, 1992-1993. Rev. Soc. bras. Med. trop., 27: 217-220, 1994.

8. DACINGER, M. \& LOPEZ, M. - Number of Giardia in the feces of infected children. Amer. J. trop. Med. Hyg., 24: 237-242, 1975.

9. FARTHING, M.J.G. - Host parasite interactions in human giardiasis. Quart. J. Med., 70: 191-204, 1989.

10. GOLDIN, A.J.; WERNER, A.P.T.; AGUILERA, X. et al. - Efficient diagnosis of giardiasis among nursery and primary school children in Santiago, Chile by capture ELISA for the detection of fecal Giardia antigens. Amer. J. trop. Med. Hyg., 42: 538-545, 1990.
11.GREEN, E.L.; MILLES, M.A. \& WARHURST, D.C. - Immunodiagnostic detection of Giardia antigen in faeces by a rapid visual enzyme-linked immunosorbent assay. Lancet, 2: 691-693, 1985.

12.GUIMARÃES, S. \& SOGAYAR, M.I.L. - Occurrence of Giardia lamblia in children of municipal day-care centers from Botucatu, São Paulo State, Brazil. Rev. Inst. Med. trop. S. Paulo, 37: 501-506, 1995.

13.JANOFF, E.N.; CRAFT, J.C.; PICKERING, L.B. et al. - Diagnosis of Giardia lamblia infections by detection of specific antigens. J. clin. Microbiol., 27: 431-435, 1989.

14. KNISLEY, C.V.; ENGELKIRK, P.G.; PICKERING, L.K.; WEST, M.S. \& JANOFF, E.N. - Rapid detection of Giardia antigen in stool with the use of enzyme immunoassays. Amer. J. clin. Path., 91: 704-708, 1989.

15. MEYER, E.A. \& RADULESCU, S. - Giardia and giardiasis. Advanc. Parasit., 17: 1-47, 1979.

16. NAIK, S.R.; RAU, N.R. \& VINAYAK, V.R. - A comparative evaluation of three samples, jejunal aspirate and jejunal mucosal impression in the diagnosis of giardiasis. Ann. trop. Med. Parasit., 72: 491-492, 1978.

17. NASH, T.E.; HERRINGTON, D.A. \& LEVINE, M.M. - Usefulness of an enzyme-linked immunosorbent assay for detection of Giardia antigen in feces. J. clin. Microbiol. 25: 1169-1171, 1987.

18. NUNES, M.P.O.; COSTA, M.S.G.; NUNES, J.F.L.; SILVA, E.M.A. \& DANTAS, M.F.A. - Avaliação dos métodos de Faust e cols., de Hoffman e cols., de Baerman modificado, utilizados na rotina sistemática, para o diagnóstico das enteroparasitoses. Rev. bras. Anál. clín., 25: 25-26, 1993.

19. RENDTORFF, R.C. - The experimental transmission of human intestinal protozoan parasites II. Giardia lamblia cysts given in capsules. Amer. J. Hyg., 59: 209-222, 1954.

20. ROCHA, M.O.; PIRES, E.M.; SILVA, M.E.V.; NOGUEIRA, E.S. \& FLAUZINA, A.P. Prevalência de parasitas intestinais em uma amostra da população do Bairro Lindéia -Belo Horizonte, Brasil. Rev. Farm. Bioq. Univ. Fed. Minas Gerais, 5: 107-112, 1983.

21. ROSOFF, J.D.; SANDERS, C.A.; SONNAD, S.S. et al. - Stool diagnosis of giardiasis using a commercially available enzyme immunoassay to detect Giardia-Specific Antigen 65 (GSA 65). J. clin. Microbiol., 27: 1977-2002, 1989.

22. ROSOFF, J.D. \& STIBBS, H.H. - Isolation and identification of Giardia lamblia specific stool antigen (GSA 65) useful in coprodiagnosis of giardiasis. J. clin. Microbiol., 23: 905-910, 1986.

23. SCHANTZ, P.M. - Parasitic zoonoses in perspective. Int. J. Parasit., 21: 161-170, 1990 apud THOMPSON, R.C.A.; REYNOLDSON, J.A. \& MENDIS, A.H.W. - Giardia and giardiasis. Advanc. Parasit., 32: 71-160, 1993.

24. SCHEFFLER, E.H. \& VAN-ETTA, L.L. - Evaluation of rapid commercial enzyme immunoassay for detection of Giardia lamblia in formalin-preserved specimens. J. clin. Microbiol., 32: 1807-1808, 1994.

25. STIBBS, H.H.; SAMADPOUR, M. \& MANNING, J.F. - Enzyme immunoassay for detection of Giardia lamblia cyst antigens in formalin-fixed and unfixed human stool. J. clin. Microbiol., 25: 1665-1669, 1988.

26. THOMPSON, R.C.A.; REYNOLDSON, J.A. \& MENDIS, A.H.W. - Giardia and giardiasis. Advanc. Parasit., 32: 1-160, 1993.

27. TORRES, D.M.A.G.V.; CHIEFFI, P.P.; COSTA, W.A. \& KUDZIELICS, E. - Giardíase em creches mantidas pela Prefeitura do Município de São Paulo, 1982/1983. Rev. Inst. Med. trop. S. Paulo, 33: 137-142, 1991.

28. UNGAR, B.L.P.; YOLKEN, R.H.; NASH, T.E. \& QUINN, T.C. - Enzyme-linked immunosorbent assay for the detection of Giardia lamblia in fecal specimens. J. infect. Dis., 149: 90-97, 1984.

Received: 28 July 1998

Accepted: 25 February 1999 